\title{
The Business-University Cooperation Practice of UK Universities
}

\author{
Yan CHEN \\ Business school, Shandong polytechnic university, Jinan, China
}

\begin{abstract}
Business-university cooperation which is regarded as a necessary way to the realization of the university' social service mission has been attached great importance to. UK universities had been the earliest explorer in this field. Since 1960s, with promotion of government, they have achieved considerable development. We study the background and the practice of UK Business-universities, then concluded that: the government play an important role in promoting the cooperation; the UK business-university cooperation is a bi-directional, multi-dimensional relationship which features courses certification, sandwich degree program, and science parks etc. The experience is important reference to Chinese universities..
\end{abstract}

Keywords: UK universities; businessuniversity cooperation; practical experience

\section{Introduction}

After World War II, higher education "third mission" - social service functions are generally recognized in the process of economic recovery and revitalization, the connections and cooperation between universities and industries are therefore increasingly close. "Just as castles provided the source of strength for medieval towns, and factories provided prosperity in the industrial age, universities are the source of strength in the knowledge based economy of the twenty - first cen- tury. (Lord Dearing, 2002). ${ }^{[1]}$ The era of knowledge economy need more competent and ambitious talents, innovative products and technologies, as well as the world class scientific research than ever before. That, universities should strengthen cooperation with the industry, rather than confined to the "ivory tower", has become the consensus of the world higher education sector. In developed countries, such as Britain, the United States, Germany and Japan, great importance has been attached to the business-university cooperation in higher education sector. Britain is the birthplace of higher education, and known for the knowledgecentric elite education, but also the first out of the ivory tower, explored businessuniversity cooperation paths. Putting a high value on business-university cooperation is the tradition of the UK universities, more than that, UK universities also trying to build the world class businessuniversity cooperation to better serve social and economic development in the UK. ${ }^{[2]}$

\section{A brief history of UK business - university cooperation}

The business - university collaboration in UK began with the Industrial Revolution. In the late 19th century, industrial and commercial developed rapidly, the traditional elite education has been unable to meet the social needs for science, technology and talents had a great need for new educational institutions to prepare a sufficient number of professional and 
technical personnel. At the same time, the United States, Germany and other countries, with rapid technology and economic development, came from behind quickly and catch up with the UK. It caused the panic of the British government and businessmen. In this context, a number of city colleges which found by local businessmen had been set up in some important industrial cities. Different from the classical universities, the emerging city colleges were founded by industrial capital, focused on training senior technical personnel and servicing for the local community. This is the primary universityindustry cooperation model. It showed that the UK higher education sector adapted itself to the new commercial and industrial development needs.

In 1960s, the British government stressed that higher education should strengthen links with the industry and commerce, therefor meet the needs of the postwar economic and social reconstruction, and service for the social and economic development more effectively. In 1963, the British government issued the Robbins Report, a forecasting and planning report on the development of higher education in UK. The report pointed higher education's goal is to change the traditional training preachers, judges, lawyers and doctors, and provide people with the skills and talents needed in the social life of competition, the chief goal of the national education policy was that those who have the ability, condition, aspirations to receive higher education have access to higher education. That was later known as the Robbins principle. Robbins principle had a revolutionary effect on the higher education development afterwards in UK, and then led to the era of mass higher education. In this context, vocational education developed vigorously in the United Kingdom, more than 30 multidisciplinary institute of technology had been established. City colleges, multidis- ciplinary institutes of technology had natural links with industry from established. In 1990s, the UK government reformed the education system, and then multidisciplinary technical colleges were upgraded to universities. Business university cooperation-oriented is no longer the exclusive features of the city universities and institutes of technology, but the characteristic of the UK higher education system as a whole. The traditional universities including Oxford and Cambridge began to value cooperation with industries, since then business university cooperation gradually rooted in the academic tradition of British higher education.

\section{The business-university coopera- tion practice of the UK universities}

\subsection{A bi-directional, multi- dimensional business - university relationship}

In the initial stage of business-university relations, the two are not mutually contact; with the development of science and technology, unidirectional and accidental contact between business and universities appeared; thus there would be more and more both way interaction; finally, a mature, functions partially overlap and cooperative relations would be formed. ${ }^{[3]}$ The UK higher education is in the final stage. Driven by the government, the business-university cooperation had a great development both in depth and breadth. The relationship between universities and industries has transformed from unidirectional links, which universities are seen as simple linear supplier of talents and research to business, bidirectional and multi-dimensional business-university cooperation and interaction which means universities are an integral part of the skills and innovation supply chain to business. Business- 
university cooperation and interaction has been deeply rooted in the academic tradition of contemporary British universities. Many university admissions handbooks have detailed instructions on businessuniversity cooperation resources, which would be regarded as an advantage of the university's educational resources. Universities often establish cooperative relations by "one-to-many" mode that a university establishes strategic partnerships in various fields of expertise, while the business side is seeking universities to be able to best meet their needs. For example the strategic partners of Manchester Business School included ICAEW (the Institute of Chartered Accountants in England and Wales ), KPMG, Ernst \& Young, Deloitte \& Touche, Accenture, IBM HP, Intel, Unilever, SAS, Fujitsu etc. ${ }^{[4]}$

\subsection{Business-university cooperation in personnel training practice}

In the context of mass higher education and marketization, there is fierce competition both in enrollment market and job market, therefor training graduates with excellent employability become one of the important missions of higher education. The main approach that the universities cultivate employability is to narrow the distance between universities and the market through the cooperation of industry parties.

By inviting the business partners to design the curriculums, the latest industrial demands can be involved. Part of the Manchester Business School courses are certificated by more than 60 companies such as Credit Suisse, and students who take these certification courses, would have professional comparative advantage. Business participating in course designing makes the courses to keep relevance and quality with business, and also im- prove the possibility of graduate recruitment.

Moreover, the business partners also provided guru lectures, skills workshops and employer mentoring schemes. Students have complete team projects set by partner companies in their curriculums. Thus, universities can introduce real work experience in the curriculum, and make learning and working practices closely linked.

In addition, the business partners provide completed placements and internships. Through the placements, many UK universities set sandwich degree programs, which is typically British model. Students who joined the sandwich programs would enter the placement to work in the third year. That will be helpful to improve important transferable skills and gain a real insight into the world of work. While the business partners would take this arrangement as part of their recruitment management, it will be helpful for improving recruitment efficiency by understanding and communication before the formal recruitment. In 2009/2010, $85 \%$ of AGR (Graduate Recruitment Association) members provided placements or internships with $20 \%$ reported that they admitted previous sandwiches or internship graduates for more than $60 \%$ of the jobs. [5]

\subsection{Business-university cooperation practice in research and innova- tion}

Over the past 50 years, the UK universities born more than 40 Nobel laureates, excellence in research capacity are internationally recognized and rank second only to the United States in this regard. ${ }^{[6]}$ British universities as an important academic and research institutions undertake the majority of basic and applied research. In 1970s, due to the recession, the government slashed financial budget, including higher education budget, and led to 
business-university cooperation promoted. In 1980s, a large number of high-tech companies emerged around the Cambridge University, and gradually formed a famous science park. Science parks based on the universities' research and invention, took full advantage of the talents and resources of the universities to establish $\mathrm{R}$ $\& \mathrm{D}$ and incubator parks. Science parks integrated the universities' features professional to form a high-tech industry with vigor and vitality.

The establishment of courses are certificated and technology incubator is another typically British businessuniversity cooperation practice in research and innovation. Science and technology incubators are operated like an enterprise. The board of directors is made up of three parts: universities, local governments, and investors. The aim of incubator is to encourage teachers to start a business in incubators, commercialize research results. Teachers invested with intangible assets. Science incubators are generally built in the vicinity of the universities. The university usually set up a dedicated service agency to assist in the operation of the incubator. Companies applied to join the incubator are generally high-tech enterprises. The project should have a close relationship with the university research. The feasibility and potential of the business plan also should go through a rigorous evaluation and audit before admitted by the incubator. Incubator is a commercial operation similar to the venture capital, which is characterized by closely associated with the research expertise of the university. Oxford and Cambridge have their own incubators.

In summary, the contemporary business-university cooperation in UK is the promoted by government, the government plays a very important role of cata- lyst, therefore ,the business-university cooperation is a tripartite relationship and mechanisms with government, universities and business. The characteristic of business-university relationship is bidirectional, multi-dimensional and functions overlapped. The practice of UK universities in business-university cooperation provided very valuable experience for China that faced the same situation, such as mass and marketization higher education, global competition and so on.

\section{References}

[1] Professor Sir Tim Wilson DL .A Review of Business-University Collaboration.

http://www.bis.gov.uk/policies/higher -education.

[2] Department for Business Innovation \& Skills (BIS). "Higher Education White Paper: Students at the Heart of the System", pp. 6, 2011.

[3] Hui Cheungching, "New BusinessUniversity Partnerships: from the UK Experience," Proc. Higher Education Exploration, pp. 63,2009 (1)

[4] University of Manchester Courses: Accounting, Management and Information Systems .http://www.manchester.ac.uk/u ndergraduate/courses/search2012/atoz /course/?code $=08959 \& p g=$ all

[5] Professor Sir Tim Wilson DL, "A Review of Business-University Collaboration", pp.70 http://www.bis.gov.uk/policies/higher -education.

[6] Wang Lu, You Rui, "Evaluation and Competition: The Basis and Principles for Research Funding of British Universities," Proc. Foreign Educational Research, pp.65,2008(2). 